Republic of Denial 
This page intentionally left blank 


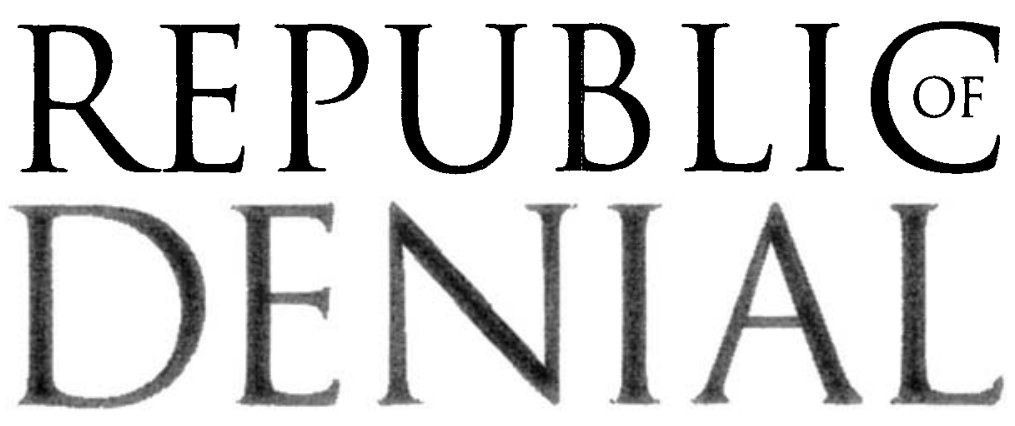

Press, Politics,

and Public Life

\section{Michael Janeway}

Yale University Press

New Haven \& London

然 
Copyright $(1999$ by Yale University. All rights reserved.

This book may not be reproduced, in whole or in part, including illustrations, in any form (beyond that copying permitted by Sections I07 and I08 of the U.S. Copyright Law and except by reviewers for the public press), without written permission from the publishers.

Lyric excerpts of "Can You Use Any Money Today?" by Irving Berlin (page 20) copyright $(1) 1950$ by Irving Berlin. Copyright renewed. International copyright secured. All rights reserved. Reprinted by permission.

Portions of the introduction and chapter 4 appeared in different form in "Power and Weakness of the Press," the Freedom Forum Media Studies Journal, fall 1991. Portions of chapters 5 and 6 appeared in different form in "The Press and Privacy: Rights and Rules," in The Morality of the Mass Media, W. Lawson Taitte, ed. (University of Texas at Dallas, 1993).

Designed by April Leidig-Higgins.

Set in Sabon type by Keystone Typesetting, Inc., Orwigsburg, Pennsylvania.

Printed in the United States of America

Library of Congress Cataloging-in-Publication Data Janeway, Michael, 1940- Republic of denial : press, politics, and public life / Michael Janeway.

p. cm. Includes bibliographical references and index. ISBN: 978-0-300-08906-6

I. Press and politics - United States. 2. Journalism-Political aspects - United States. 3. United States - Politics and government - 2oth century. PN4888.P6J36 I999 O7I'.3-dc2I 99-30453

A catalogue record for this book is available from the British Library.

The paper in this book meets the guidelines for permanence and durability of the Committee on Production Guidelines for Book Longevity of the Council on Library Resources. 